Original Research Paper

\title{
HUBUNGAN ANTARA MEROKOK DENGAN GAMBARAN FUNGSI GINJAL PADA KARYAWAN PT.X
}

\author{
${ }^{* 1}$ Nur Syamsi, ${ }^{1}$ Andi Alfia Muthmainnah Tanra, ${ }^{2}$ Mariani Rasjid HS \\ ${ }^{1}$ Departemen Farmakologi, Fakultas Kedokteran, Universitas Tadulako \\ ${ }^{2}$ KSM RSU Tadulako Palu, Fakultas Kedokteran, Universitas Tadulako
}

Email Corresponding:

nursyamsiyusuf@gmail.com

Page : $147-152$

\section{Kata Kunci :}

merokok,

fungsi ginjal,

urea,

kreatinin,

eGFR

\section{Keywords:}

smoking,

renal function,

urea,

creatinine,

$e G F R$

Published by:

Tadulako University,

Managed by Faculty of Medicine.

Email: healthytadulako@gmail.com

Phone (WA): +6285242303103

Address:

Jalan Soekarno Hatta Km. 9. City of

Palu, Central Sulawesi, Indonesia
Penyakit ginjal kronis merupakan masalah kesehatan global dengan prevalensi dan insidens yang terus meningkat serta prognosis yang buruk. Oleh karena itu, dibutuhkan identifikasi faktor risiko terutama yang bisa dimodifikasi dan dikendalikan untuk menekan kejadiannya. Salah satu faktor risikonya adalah kebiasaan merokok. Tujuan penelitian ini adalah untuk mengetahui hubungan merokok dengan profil fungsi ginjal pada karyawan PT.X. Jenis penelitian yang dilakukan adalah deskriptif analitik dengan desain cross sectional berdasarkan kebiasaan merokok dan sampel tes darah karyawan. Sampel dalam penelitian ini adalah 40 karyawan PT.X yang ditentukan secara consecutive sampling. Hasil penelitian menunjukkan bahwa tidak ada hubungan antara merokok dengan usia $(\mathrm{p}=0,222)$ dan azotemia $(\mathrm{p}=1,00)$ tetapi ada hubungan antara merokok dan kadar kreatinin darah $(\mathrm{p}=0,001)$, urea $(\mathrm{p}=0,023)$, eGFR $(\mathrm{p} .=0,001)$, dan stadium penyakit ginjal kronis $(\mathrm{p}=0,047)$. Berdasarkan hasil penelitian dapat disimpulkan bahwa terdapat hubungan antara merokok dengan profil fungsi ginjal pada karyawan PT. X.

\section{ABSTRACT}

The chronic kidney disease is a global health problem with increasing prevalence and incidence and a poor prognosis. Therefore, those brought about by risk factors are primarily those which can be modified and controlled for their occurrence. One of the risk factor is smoking habit. The objective of this study was to determine the associations between smoking and renal function profiles in PT.X employees. The study was conducted by using descriptive analytical study with a cross sectional design based on smoking habits and blood test samples of employees. The sample were 40 employees in PT.X which determined by consecutive sampling. The results showed that there were no associations between smoking with age $(p=0.222)$ and azotemia $(p=1.00)$ but there were associations between smoking and blood creatinine levels $(p=0.001)$, urea $(p=$ $0.023), e G F R(p .=0.001)$, and the stages of chronic kidney disease $(p=0.047)$. Based on the study results, in can be concluded that there were associations between smoking and renal function profiles among employees of PT. $X$

\section{PENDAHULUAN}

Penyakit ginjal kronis (PGK) merupakan masalah kesehatan masyarakat global dengan prevalensi dan insidens yang terus meningkat. Penyakit tersebut juga memiliki prognosis yang buruk sehingga membutuhkan biaya pengobatan yang tinggi. Prevalensi PGK meningkat seiring meningkatnya jumlah penduduk usia lanjut dan kejadian penyakit diabetes melitus serta hipertensi. Sekitar 1 dari
10 populasi global mengalami PGK pada stadium tertentu. Menurut hasil Global Burden of Disease tahun 2010, PGK merupakan penyebab kematian peringkat ke-27 di dunia tahun 1990 dan meningkat menjadi urutan ke18 pada tahun 2010. Sedangkan di Indonesia, perawatan penyakit ginjal merupakan ranking kedua pembiayaan terbesar dari BPJS kesehatan setelah penyakit jantung. Berdasarkan Riskesdas tahun 2013, 
provinsi dengan prevalensi tertinggi adalah Sulawesi Tengah sebesar $0,5 \%$, diikuti Aceh, Gorontalo, dan Sulawesi Utara masing-masing $0,4 \%{ }^{1}$.

Hasil Riskesdas 2013, penduduk Indonesia yang terdiagnosis penyakit ginjal kronis hanya sebesar $0,2 \%$. Angka ini lebih rendah dibandingkan dengan prevalensi penyakit ginjal kronis di negara lain, karena sebagian besar penyakit ginjal kronis di Indonesia baru terdiagnosis pada tahap lanjut dan akhir. Berdasarkan hasil Riskesdas 2013 pula, provinsi dengan prevalensi tertinggi adalah Sulawesi Tengah sebesar 0,5\%, diikuti Aceh, Gorontalo, dan Sulawesi Utara masingmasing $0,4 \%$ 1. Penyakit ginjal kronis dihasilkan dari interaksi yang kompleks antara genetik (faktor yang tidak dapat dimodifikasi) dan faktor lingkungan (faktor yang dapat dimodifikasi). Identifikasi faktor-faktor risiko yang dapat dimodifikasi dan dikendalikan merupakan langkah penting untuk mengurangi insiden penyakit tersebut ${ }^{2}$.

Merokok merupakan salah satu faktor risiko utama terjadinya penyakit kronik salah satunya penyakit ginjal kronik. Beberapa hasil penelitian menyebutkan bahwa terdapat penurunan filtrasi glomerulus pada pria dan wanita yang merokok dibandingkan dengan yang tidak atau sudah berhenti merokok. Teori yang mendasari terjadinya hal ini adalah nikotin dapat menginduksi hipertensi intraglomerular yang diikuti dengan hiperfiltrasi glomerular ${ }^{1,3}$. Oleh karena latar belakang tersebut, penelitian ini bertujuan untuk menilai hubungan antara kebiasaan merokok dengan gangguan fungsi ginjal.

\section{BAHAN DAN CARA}

Jenis penelitian ini adalah penelitian deskriptif analitik dengan desain casecontrol. Penelitian ini dilaksanakan pada bulan April - Juni 2020 dan bertempat di Laboratorium Klinik Maxima Cabang Palu. Sampel diambil dengan menggunakan teknik purposive sampling dengan jumlah responden sebanyak 40 orang yang memenuhi kriteria inklusi dan eksklusi. Perokok aktif didefinisikan berdasarkan status merokok yang dilaporkan sendiri sebagai mereka yang saat ini merokok setidaknya satu batang per hari. Non-perokok didefinisikan sebagai mereka yang tidak pernah merokok atau shisha dalam hidup mereka. Kedua kelompok tidak menunjukkan gejala dan belum memiliki riwayat penyakit ginjal (asimptomatik). Mereka yang menderita diabetes, hipertensi, terkena zat nefrotoksik (pekerjaan atau rekreasi), atau menerima analgesik jangka panjang dikeluarkan dari penelitian. Data dianalisis menggunakan SPSS 25.

\section{HASIL}

Penelitian ini melibatkan total 40 orang. Dari 40 orang tersebut terbagi atas 2 kelompok yaitu kelompok perokok dan kelompok bukan perokok yang masing-masing terdiri atas 20 orang untuk tiap kelompok.

Tabel 1. Karakteristik sampel

\begin{tabular}{llcc}
\hline & & Frekuensi (n) & Persentase (\%) \\
\hline Usia & $16-40$ & 25 & 62.5 \\
\multirow{4}{*}{ Ureum } & $>40$ & 15 & 37.5 \\
\multirow{3}{*}{ Kreatinin } & normal & 16 & 40 \\
& tidak normal & 24 & 60 \\
\multirow{3}{*}{ Stadium fungsi ginjal } & 39 & 97.5 \\
& normal & 1 & 2.5 \\
& tidak normal & 21 & 52.5 \\
& normal & 18 & 45 \\
& disfungsi ginjal ringan & 1 & 2.5 \\
\hline
\end{tabular}


Tabel 2. Hubungan status merokok dengan rerata kadar kreatinin serum, kadar ureum, laju filtrasi glomerulus, dan stadium fungsi ginjal

\begin{tabular}{|c|c|c|c|c|c|c|}
\hline & & \multicolumn{2}{|c|}{ Perokok } & \multicolumn{2}{|c|}{ Bukan Perokok } & Nilai $p$ \\
\hline \multicolumn{2}{|l|}{ Kreatinin } & \multicolumn{2}{|c|}{$0.99(0.11)$} & \multicolumn{2}{|c|}{$0.86(0.18)$} & 0.001 \\
\hline \multicolumn{2}{|l|}{ Ureum } & \multicolumn{2}{|c|}{$21(15 \pm 24)$} & \multicolumn{2}{|c|}{$23,5(18 \pm 32)$} & 0,023 \\
\hline \multicolumn{2}{|l|}{$e G F R$} & \multicolumn{2}{|c|}{$96,07(81,32 \pm 146,40)$} & \multicolumn{2}{|c|}{$86,30(55,52 \pm 95,92)$} & 0,001 \\
\hline & & $\mathrm{n}$ & $\%$ & $\mathrm{n}$ & $\%$ & Nilai $\mathrm{p}$ \\
\hline \multirow{3}{*}{$\begin{array}{l}\text { Stadium } \\
\text { fungsi } \\
\text { ginjal }\end{array}$} & Normal & 7 & 35 & 14 & 70 & 0.047 \\
\hline & $\begin{array}{l}\text { Disfungsi } \\
\text { ginjal ringan }\end{array}$ & 12 & 60 & 6 & 30 & \\
\hline & $\begin{array}{l}\text { PGK stadium } \\
\text { menengah }\end{array}$ & 1 & 5 & 0 & 0 & \\
\hline
\end{tabular}

Kelompok perokok memiliki rerata kadar creatinin serum dan kadar ureum yang lebih tinggi dibandingkan dengan kelompok bukan perokok. Berbeda halnya dengan laju filtrasi glomerulus, kelompok perokok memiliki rerata lebih rendah dibandingkan kelompok yang bukan perokok. Berdasarkan stadium fungsi ginjal, pada kelompok perokok ditemukan lebih banyak (60\%) yang mengalami disfungsi ginjal ringan dibandingkan kelompok bukan perokok. Pada kelompok perokok didapatkan 1 sampel yang termasuk dalam kategori penyakit ginjal kronik stadium menengah.

\section{PEMBAHASAN}

Penelitian ini menunjukkan hubungan yang erat antara kebiasaan merokok dengan status fungsi ginjal, terlepas dari faktor risiko lainnya. Hubungan antara kebiasaan merokok dengan status fungsi ginjal divalidasi dengan nilai eGFR yang dihitung menggunakan rumus MDRD, berdasarkan usia dan kadar kreatinin serum masing-masing sampel.

Hasil penelitian menunjukkan bahwa ada peningkatan kadar kreatinin serum pada kelompok perokok dibandingkan kelompok tidak merokok. Hasil serupa didapatkan pada penelitian studi kasus-kontrol retrospektif dari 4142 peserta nondiabetes (berusia> 65 tahun) dari Kelompok Studi Kesehatan
Kardiovaskular, menyatakan bahwa ada peningkatan risiko peningkatan kreatinin serum $(0,3 \mathrm{mg} / \mathrm{dL})$ dengan peningkatan penggunaan tembakau selama periode waktu 3 tahun ${ }^{4}$. Penelitian yang dilakukan oleh Hogan et al., (2009) menunjukkan adanya hubungan antara kebiasaan merokok dan peningkatan kreatinin serum.

Berdasarkan hasil analisis, didapatkan bahwa ada peningkatan kadar ureum pada kelompok perokok dibandingkan dengan kelompok kontrol. Peningkatan kadar ureum pada orang merokok juga didapatkan pada penelitian cross-sectional melibatkan 3033 sampel di Cina ${ }^{6}$, begitu juga dengan hasil penelitian case-control pada 80 laki-laki Sudan ${ }^{7}$, dan pada penelitian cross-sectional pada 85 orang sampel terbagi ke dalam tiga kelompok sampel (perokok berat, moderat, dan bukan perokok) ${ }^{8}$. Hal ini terjadi karena merokok meningkatkan resistensi renovaskular yang menyebabkan penurunan yang signifikan pada laju filtrasi glomerulus (GFR), fraksi filtrasi dan darah plasma ginjal. Penurunan GFR akan menyebabkan penurunan laju aliran tubular distal yang menyebabkan peningkatan reabsorpsi ureum ${ }^{8}$.

Studi ini mengamati hubungan antara kebiasaan merokok dan gambaran fungsi ginjal yang salah satunya ditandai oleh penurunan laju filtrasi glomerulus. 
Berdasarkan analisis, kebiasaan merokok berhubungan signifikan dengan penurunan laju filtrasi glomerulus, hasil yang didapatkan sesuai dengan hasil penelitian yang dilakukan oleh Hogan et al., pada tahun 2009. Suatu penelitian menggunakan animal model yang membandingkan efek paparan asap rokok antara tikus jantan dan tikus betina, menunjukkan hasil bahwa setelah 6 minggu terpapar asap rokok, tikus jantan menunjukkan stadium lanjut kerusakan glomerulotubular yang ditandai dengan fibrotik, inflamasi, mengecilnya ukuran kapsul Bowman, dan penurunan diameter tubular yang lebih signifikan dibandingkan tikus betina ${ }^{9}$.

Beberapa mekanisme potensial untuk efek merokok pada ginjal mungkin dimediasi melalui kombinasi efek, termasuk perubahan hemodinamik ginjal dan tekanan darah serta kerusakan mikrovaskulatur di dalam ginjal. Telah dihipotesiskan bahwa efek aterogenik dari merokok meluas ke mikrovaskuler ginjal, mempengaruhi struktur tubulus ginjal dan glomerulus. Hasil otopsi telah mendukung teori ini dan telah menunjukkan hubungan antara riwayat merokok dan penebalan arteriol ginjal. Konsentrasi kadmium darah pada perokok sekitar empat kali lebih tinggi dibandingkan pada bukan perokok, dan kadmium juga telah terlibat dalam perkembangan penyakit ginjal. Kadmium adalah polutan lingkungan dengan sifat nefrotoksik yang diserap ke dalam tubuh oleh, antara lain, merokok, dan memiliki laju ekskresi yang lambat karena reabsorpsi ginjal. Efek nefrotoksisitas kadmium mungkin termasuk proteinuria, kalsituria, glikosuria, dan nekrosis tubular. Juga, karena waktu paruh yang ekstensif (30 tahun), eksposur kronis tingkat rendah terhadap kadmium juga merugikan dan mungkin terkait dengan penyakit ginjal stadium akhir, penyakit ginjal diabetes onset dini, dan regulasi tekanan darah abnormal $^{5,10}$.

Hasil penelitian ini konsisten dengan beberapa penelitian lainnya yang telah meneliti hubungan antara kebiasaan merokok dengan stadium fungsi ginjal. Sebuah artikel review melaporkan merokok merupakan faktor risiko perkembangan $\mathrm{CKD}{ }^{11}$. Dalam sebuah penelitian terhadap > 65.000 orang Norwegia yang diikuti selama rata-rata 10,3 tahun, merokok sebelumnya dan saat ini secara signifikan dikaitkan dengan risiko gagal ginjal dibandingkan dengan tidak pernah merokok (rasio hazard masing-masing 3,32 dan 4,01) ${ }^{4}$.

Hasil penelitian cross-sectional lainnya menunjukkan hubungan antara paparan merokok dengan kerusakan ginjal dini dan kejadian albuminuria pada populasi Amerika Serikat. Albuminuria didefinisikan sebagai albumin-to-creatinin ratio (ACR) urine $\geq 17$ $\mu \mathrm{g} / \mathrm{mg}$ pada pria dan $\geq 25 \mu \mathrm{g} / \mathrm{mg}$ pada wanita 5. Hasil yang sama juga dikemukakan oleh Tada et al., (2019) bahwa bahwa merokok meningkatkan risiko timbulnya CKD baru pada populasi Jepang. Salah satu penelitian multisenter di Indonesia menggunakan desain kasus kontrol dengan padanan jenis kelamin dan menggunakan perbandingan kasus dan kontrol 1:1 untuk mengidentifikasi faktor risiko penyakit ginjal kronik dengan jumlah sampel sebesar 858 orang menyatakan kebiasaan merokok tidak berhubungan secara signifikan dengan penyakit ginjal kronik, namun tidak dapat dikesampingkan karena hasil penelitian menunjukkan kebiasaan merokok meningkatkan risiko penyakit ginjal kronik 1,39 kali dibandingkan dengan sampel yang tidak merokok ${ }^{13}$.

\section{Peningkatan reactive oxygen species} (ROS) dan proses inflamasi merupakan mekanisme yang dapat diinduksi oleh asap rokok. Asap rokok mengandung sekitar 4000 senyawa kimia seperti karbon monoksida, karbon dioksida, fenol, amonia, formaldehid, piren, nitrosamin, nikotin, tar, cadmium, dan timbal yang sangat berbahaya bagi tubuh manusia. Asap rokok juga terdiri dari berbagai oksidan dan radikal bebas yang bisa merusak 
lipid, protein, deoxyribonucleic acid (DNA), karbohidrat serta berbagai biomolekul lainnya 14. Kadmium, timbal, dan nikotin merupakan kandungan asap rokok yang terbukti bersifat nefrotoksik. Nikotin diketahui meningkatkan fibrosis dan inflamasi pada tubulus proksimal dan menginduksi apoptosis pada sel podosit ginjal 9 . Mukosa hati, ginjal, paru-paru dan mulut adalah organ tubuh yang terlibat dalam pengaturan metabolisme nikotin yang merusak sistem kardiovaskular dan kelenjar endokrin. Ginjal biasanya merespons dengan filtrasi glomerulus yang berkurang yang bertanggung jawab untuk oliguria karena penyempitan arterioloskrotik arteri resisten. Komplikasi ekstrim dari gangguan ginjal dapat berkembang menjadi gagal ginjal kronis ${ }^{15}$.

\section{KESIMPULAN DAN SARAN}

Terdapat hubungan yang signifikan antara kebiasaan merokok dengan peningkatan kadar kreatinin serum, peningkatan kadar ureum, penurunan laju filtrasi glomerulus, dan stadium fungsi ginjal.

Bagi penelitian selanjutnya, sekiranya perlu melakukan penelitian mengenai faktorfaktor yang mempengaruhi fungsi ginjal seperti tekanan darah, dan lain-lain.

\section{UCAPAN TERIMAKASIH}

Penelitian ini dibiayai oleh dana DIPA Fakultas Kedokteran Universitas Tadulako Tahun Anggaran 2020.

\section{DAFTAR PUSTAKA}

1. Depkes. Infodatin Pusat Data Dan Informasi Kementerian Kesehatan RI: Situasi Penyakit Ginjal Kronis. 2017:110.

Www.Depkes.Go.Id/Resources/Download /Pusdatin/Infodatin/.

2. Metwally FM, Mohammed AM. Impact Of Tobacco Smoking On Renal Function Tests In Asymptomatic Individuals. Int $J$ Pharm Clin Res. 2016;8(12):1629-1633.

3. Popa SG, Moţa M, Mihălţan FD, Et Al. Associations Of Smoking With
Cardiometabolic Profile And Renal Function In A Romanian PopulationBased Sample From The PREDATORR Cross-Sectional Study. Eur J Gen Pract. 2017;23(1):164-170.

Doi:10.1080/13814788.2017.1324844

4. Hall ME, Wang W, Okhomina V, Et Al. Cigarette Smoking And Chronic Kidney Disease In African Americans In The Jackson Heart Study. J Am Heart Assoc. 2016;5(6):1-6.

Doi:10.1161/JAHA.116.003280

5. Hogan SL, Hogan SL, Vupputuri S, Et Al. Association Of Cigarette Smoking With Albuminuria In The United States: The Third National Health And Nutrition Examination Survey. Ren Fail. 2009;29(2):133-142.

Doi:10.1080/08860220601098888

6. Huang F, Chen J, Liu X, Et Al. Cigarette Smoking Reduced Renal Function Deterioration In Hypertensive Patients May Be Mediated By Elevated Homocysteine.

Oncotarget.

2016;7(52):86000-86010.

Doi:10.18632/Oncotarget.13308

7. Mohamed M, Ahmed E, Osman HM, Shayoub M. The Effect Of Smoking Cigarette On Kidney Functions Among Sundaes Peoples. Int $J$ Dev Res. 2015;(May):3-6.

Http://Www.Journalijdr.Com.

8. Haider B. The Effect Of Smoking Cigarette On Kidney Functions. 2019:020.

9. Kaplan A, Abidi E, Habeichi NJ, Et Al. Gender-Biased Kidney Damage In Mice Following Exposure To Tobacco Cigarette Smoke: More Protection In Premenopausal Females. Physiol Rep. 2020;8(2):1-17.

Doi:10.14814/Phy2.14339

10. Price RG. Cadmium Nephropathy And Smoking. Clin Med Insights Urol. 2017;10:117956111772609.

Doi: $10.1177 / 1179561117726090$

11. Elihimas Júnior UF, Elihimas HC Dos S, Lemos VM, Et Al. Smoking As Risk Factor For Chronic Kidney Disease: Systematic Review. J Bras Nefrol. 2014;36(4):519-528. Doi:10.5935/01012800.20140074 
12. Tada K, ITO K, Maeda T, Et Al. SUN250 Cigarette Smoking Influence The New-Onset Of Chronic Kidney Disease: Iki Epidemiological Study Of Artherosclerosis And Chronic Kidney Disease (ISSA-CKD) Retrospective Phase. Kidney Int Reports. 2019;4(7):S263.

Doi:10.1016/J.Ekir.2019.05.655

13. Delima D, Tjitra E. Faktor Risiko Penyakit Ginjal Kronik: Studi Kasus Kontrol Di Empat Rumah Sakit Di Jakarta Tahun 2014. Bul Penelit Kesehat.
2017;45(1):17-26.

Doi:10.22435/Bpk.V45i1.7328.17-26

14. Wibowo D V, Pangemanan DHC, Polii H. Hubungan Merokok Dengan Kadar Hemoglobin Dan Trombosit Pada Perokok Dewasa. J E-Biomedik. 2017;5(2).

Doi:10.35790/Ebm.5.2.2017.18510

15. Leone A. How And Why Chemicals From Tobacco Smoke Can Induce A Rise In Blood Pressure. World J Pharmacol. 2012;1(1):10. Doi:10.5497/Wjp.V1.I1.10 